iRASD Journal of Management

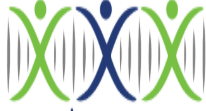

IRASD
Volume 3, Number 3, 2021, Pages 208 - 217

Journal Homepage:

https://journals.internationalrasd.org/index.php/jom

\title{
The Role of Human Rights and Obligations toward Cross Gender Empowerment under the domain of Islamic Laws
}

\author{
Salma Nawaz ${ }^{1}$, Malik Shahzad Shabbir ${ }^{2}$, Kanwal Shaheen ${ }^{3}$, Mouna Koser ${ }^{4}$ \\ ${ }^{1}$ University Law college Quetta, Pakistan, Email: salmanawaz877@gmail.com \\ ${ }^{2}$ University of Lahore, Pakistan, Email: mshahzad786.pk11@gmail.com \\ ${ }^{3}$ Assistant professor, Department of Management Sciences, Government College Women University, Faisalabad, \\ Pakistan, Email: kanwalshaheen@gcwuf.edu.pk \\ ${ }^{4}$ University of Management and Technology, Pakistan, Email: mouna.koser7@gmail.com
}

\section{ARTICLE INFO}

Article History:

Received:

Revised:

Accepted:

November 12, 2021

December 12, 2021

December 25, 2021

Available Online: December 26, 2021

\section{Keywords:}

Quranic

Hadith

Women's rights

Gender Equality

\section{ABSTRACT}

This study enumerates Islamic laws regarding women rights throughout the extent of Quran and Hadith in the principal origins of Islam. It highlights toward gender equity and women rights. Islamic principles consistently accord with nature of man and woman and think about their intrinsic contrasts. Islam has ensured people (both men and women) human rights and obligations associated with them as people in an equivalent degree. What Islam ensures usually not get conveyed into solid actions because of dominant communal and ethnic standards and in context of social and cultural relations. The basic estimations of Islam ostensibly advance and respect the status of women in the public eye. Islam gave freedom to Muslim women by allowing them equivalent rights as similar to their male partners, as demonstrated by the Prophet Mohammad (PHUH) [women are identical parts or sisters in relation to men]. Numerous adamant translations of Islamic messages and practices of a larger number of Muslim societies unfortunately disagree the primary origin of women rights as well as gender equalities. Besides, it is falsly realized that Muslim females particularly are in retrograte position and are also mistreated by religion Islam as compare to nonMuslim women who are observed as liberated, modernized and forward. Thusly, this article focuses to distinguish how religion Islam has provided women their rights, liberty, equality and respect.

(C) 2021 The Authors, Published by iRASD. This is an Open Access article under the Creative Common Attribution Non-Commercial 4.0

\section{Corresponding Author's Email: mshahzad786.pk11@gmail.com}

\section{Introduction}

This study explains status and privileges of women in religion Islam and can be recognized better Islamic laws (Qur'an \& Hadith) and elaboration is likewise made concerning rights of women with regard to other religions. Holy Quran gave women the privileges of legacy, divorce and other essential rights a very long time previous to western women were concurred such rights (DW, 2020). Prophet Mohammad (PBUH) protruded liberation of women in every part of his life (PBS, 2007). It is an extensive misunderstanding in the west that according to Islam a women is substandard compared to man. They apparently imagine that in Islam women do not have any privilege or right. This misinterpretation is because of their absence of access to the Holy Quran and the conventions, and because of the flippant disposition of certain Muslim scholars. It is just Islam which gives balance among people both men and women (Elius, 2010). 
According to Holy Quran men and women are domestic partners with indistinguishable obligations and duties (Bralvi, 1982). In Western societies women needed to fight for their privileges, and after a time of constant exertion and prgamatic tussle with the opposed gender due acknowledgment was apted to them (Eide, 2008). They obtain their privileges by force, dissimilar to their Muslim partners who obtained their privileges by Divine Law. Indeed, even still, the privileges of the women of west, which they achieved after a long nexus of efforts, fail to reach target regarding those of muslim ladies. Islam has granted every rights to women that further suit their inclination and characteristics. It is Islam which gives them full assurance and security (FT, 2021). This insurance and security made women conspicuous individuals from muslim society when the western women were hostages of obliviousness and misuse. Islam is hundreds of years in advance related to the western legitimate framework, when it proclaimed people as men and women as equivalent person. Both men and women have been made equivalent, however not indistinguishable. The rights and obligations related to women are equivalent to that of men, however they are not essentially the equivalent (Kia, 2019). Their functions are disparate and they are likewise structured differently in contrast to one another, and this variety of capacities doesn't recommend that one is subordinate compared to the next. In some part of life one exceeds expectations from the other. Their jobs in life are corresponding to one another.

At Jahiz "160 to $255 \mathrm{~A} . \mathrm{H}$ " was a philosopher. He writes down in his exposition about women that; (we do not state and any sensible individual cannot state that women are supra to men or lower-class than men by a level or at least two. The respect of men require not be established upon the humiliation of women. (Dawn, 2004).

Family law, as different parts of Islamic law, gets from the idea of Tawhid, or the confidence in a solitary God. Tawhid is the center guideline of Islamic Jurisprudence (Hunter, 2008). From it stream numerous optional standards, including the one that states that God is the preeminent being and that all human are the creation of one God. Hence, the Tawhid rule give the premise to the basic otherworldly similarity of all people as creation of one and only "God". The Qur'an at that point remarks on further supernatural likenesses and observational contrasts among people. It expresses that individuals were altogether made from the equivalent nafs (soul), in this way reemphasizing their theoretical similarity. It additionally expresses that God made people from a "male and female" and created them into federations and clans, thus, they would become acquainted with (acknowledge, get to know) one another.

The Qur'an at that point includes that the most respected people in visual percept of God are the individuals who are the most devout (AL-AHSAN, 1999). Subsequently, while the Qur'an calls attention to observational contrasts among people, for example, those of sexual classification, race and social group that has a common national or cultural tradition or characteristic equality. It puts together any positioning amid them with respect to their individual decisions or behavior of right and wrong. Therefore, from the point of view of these Qur'anic entries, no man is higher or dominant than a woman by righteousness of his sexual classification alone. The Qur'an likewise makes it perfectly clear that celestial will examines a relationship of concordance, consultation, and participation, rather than strife and mastery, between the two sexes (Al-Hibri, 2000).

Men and women are basically treated as humans and are perceived as complete creatures with the obligation to satisfy their physical, passionate, intellectual and profound needs, obligations, and potential, meanwhile keeping their superior determination in life at the center of their own and public vision (Matloob, Shabbir, \& Saher, 2020; Saher, Matloob, \& Shabbir, 2020; Malik Sahhzad Shabbir, Matloob, \& Faiz, 2017). Human thriving, well beyond their behavior as appropriate to their gender, in this life as well as the life after death, is the language that is embraced in the Quranic description. It might seem like equality in gender is an imported product of Islam, with any accentuation on it the aftereffect of outside influence compelling Muslim people group to make change and practices identified with across the board related to gender discrimination and inequality (Badawi, 1995).

There are different portrayals concerning women that made huge contributions, for example, Amirah - Bint Abdul-Rehman interceded in a legal dispute in Medina and defended 
a failure of court to administer justice properly by exhibiting printed proof from religious sources oblige the Judge to turn over his judgment, without requiring a consequent statement of advice. A 12th century female researcher "Zaynab bint al-Kamal" edified in excess of 400 books of hadiths to a large number of understudies (Ahmed, 2010). Be that as it may, from the initiation of Islam, issues encompassing gender lack of equality have been of focal concern and center inside sacred text and prophetic practice, and the worldview that was developed for Muslim social orders.

There are various ways that Muslim ladies characterize themselves and their part in the public arena. This is featured by the liberal pattern of Islamic women's liberation, which is not the slightest bit a thought of western sexual classification context, however goes back to the twelfth century. Interpreters of the movement underline the profound established lessons of equity in Quran, and moreover, urge challenges toward the patriarchic centric representation of Islamic lessons for a progressively libertarian and more attractive society. Explicit issues concerning the development are, specifically, family laws and sexual nature or characteristics, yet in addition the guidelines on dress or access to instruction and business. One of the significant worries for Islamic women's liberation is additionally the solution of basic harm "prejudicial" of an existed natural feature of discrimination concerning women in religion Islam (Arif \& Shabbir, 2019; Henning, 2016; Malik Shahzad Shabbir, 2019; Malik Sahhzad Shabbir et al., 2017; Malik Shahzad Shabbir \& Zeb, 2020).

There is no uncertainty that no religion has accomplished such a great deal of what islam has done to verify and protected women's privileges. The status allowed to women by religion Islam can be recognized from the various human advancements and religions. It has no comparability in whatsoever other societies. On the off chance that we investigate the western ladies, we find that their privileges were not recognized willfully or out of generosity and empathy. The old Greek researchers had embarrassing perspectives on women. They represented as an undeniable truth that women be not complete human beings, and be ordinarily inadequate in nature. They showed specified type of temper regarding this obstinacy all through the medieval times and a similar origination was determined all through the period of enlightment. Women's considered as an encumbrance even by the aminent authors of that period, similar to Rousseau and Vottaire.

\section{Literature Review}

It is caritical that this paper depends on a unique comprehension of Islam from their unique sources (Quran and Hadith). The covering of strict understanding of sections and hadith plans to point ways that how Islam has managed gender uniformity and human rights of women. Whatever the specific technique received in pondering Islamic "talks," a significant driving force for the ongoing plenty of such activities has been the apparent new danger of far reaching lawful changes that will be adverse to women presented by strict revivalism. Everywhere in the Muslim world, the religion-based law is like a segment of the lawful framework, and a significant interest of resurgent Islam, regardless of whether in Iran, in Bangladesh, in Malaysia, in Afghanistan, in Nigeria in Algeria, in Iraq or in Sudan or somewhere else, has been amendments on account of the legitimate system. The individual status or family laws, whose basic sources are Qur'an and Islam's other holy messages.

Tending to strict principles; in this way points are not exactly at undermining regulating social thoughts of gender patriarchal bases for women submissiveness, but likewise at testing parts of existing or recommended women's hostile traditions that must be adhered to. The analysis of accepted writings as genuine and the chronicled investigation of their further elaboration by Islamic law are a vital part of the scholastic investigation of Muslim nations' lawful frameworks, frameworks that exemplify standardizing sees, yet in addition have "genuine" ramifications for women. While the investigation of religious transcripts and custom comprise some portion of lawful examinations, they are additionally just a start. The assortment of work on such frameworks and how they influence women includes some of extra strands. One significant strand tends to arrangements of the legitimate frameworks and the way the frameworks, regularly completely systematized without precedent for the twentieth century, and was assembled, consolidating segments of both Western-affected common laws and religious based laws. 
As the pre-existence, the legitimate frameworks in Islamic social orders are practically all dual frameworks. The most outstanding special cases are Tunisia and Turkey and, with their absolutely worldly and consequently unitary systems. The dual frameworks are consists of from one perspective, of a common code often Western produced with the help of inspiration, then again, an individual status or family law, basically based upon Sharia law. Comparable to law of canon inside Christianity, Sharia-law comprises of lawful arrangements that lay on translations of holy messages. Sharia statute, initially un-codified, came to be consolidated as a feature of most Muslim lawful frameworks as these came to fruition during the arrangement of present day Muslim states. The main codification of Sharia-law as Islamic Family regulation, the Ottoman. Giving little direction on numerous business matters, for instance, Sharia is held as the piece of the legitimate framework that manages individual status matters such as legal union between man and women, money or other facilities that are legally required to pay, divorces, care and custody of youngsters, inheritance, and so forth Law of Family Rights (1917).

Sharia Law is commonly just a single part belonging to a dual framework, since it is silent on numerous issues pertaining to the functions of current modern states. A decent arrangement of insightful work on the lawful circumstance of Muslim women involves itself with talk of the interaction specifically legitimate frameworks of various kinds of law. Even if the frameworks are usually dual, they vary among themselves in how much they reflect Western impacts and in which nations' persuasions they reflect. Over the span of nation building, the common codes of countries integrated Swiss, Belgian and French, components, among others. The territory of family law, moderately absolved from Western impacts as a result of the accessibility of an indigenous other option, is likewise convoluted by the different impacts. At the point when family laws were systematized and modernized over the Muslim world, they drew upon various "Sunni" schools of law (Shafi, Maliki, Hanbali, Hanafi), which contrast in the manners by which they substructure family relations, and vary also from the Shia law, comprising two schools of law (Zaydi \& Jafri). Furthermore, the family laws mix components from Islamic disciplines with highlights of local pre-Islamic or innate/ethnic traditional law, just as highlights of Western statute.

Women can, for instance, acquire any positive court judgment on an application from her husband for more than one marriage by encompassing stipulations for her marriage contract. If the woman has not delivered such stipulations dismissing plural marriage, she can go to the court to implement the statutory confinements, principally money related (Altaf, Ayub, Shabbir, \& Usman, 2021; Sadiq, Usman, Zamir, Shabbir, \& Arif, 2021; Said et al., 2021). As in a significant part of the work that addresses lawful practice, the scholars emphasizes on the point that the legitimate framework right now gives a more extensive scope of potential results and more equity for women than is normally accepted either by threatening onlookers of the framework or by religious traditionalists.

Various analysts inspired by legitimate practice, as definite from the law's content, expand upon the different procedural choices women can endeavor to bypass the evidently horrible apparent aim of the law, including one choice previously referenced, conditions in the contract of marriage, just as another choice, courses of action concerning endowment. Such alternatives take into account changes in lawful rights, in most cases with the consolation of the state, in absence of genuine changes in the existing law (Malik Shahzad Shabbir, 2020; Malik Shahzad Shabbir, Bashir, Abbasi, Yahya, \& Abbasi, 2020). An investigation of marriage agreements/contracts in Saudi Arabia demonstrates that expanding number of urban white collar class women of Saudi use stipulations in the agreement to enhance their legitimate position. In Saudi Arabia's case, the stipulations usually concern the privilege to think about and to work, yet they can incorporate a wide range. Another investigation shows that even post-revolutionary country Iran permits, yet urges the response to stipulations (Offenhauer \& Buchalter, 2005).

From the inception of religion Islam, rulers as well as judges grew better approaches for applying the customs to evolving situations. Huge numbers of these new applications included approaches to give women more prominent self-sufficiency and greater autonomy, for instance, in case of separation/divorce procedures, without deviating from the more extensive scriptural system, often by including a lawful prerequisite that marriage or separation (or different events) be completed under the protection of court. We would thus 
be able to talk about a "positivization" of Islamic commandment. In building up those actions of modifying, a few states have deflected Islamic law toward considerably noteworthy gender equality. This direction has moved quickly in the time following the II World War, specifically as recently independent countries looked to adjust and assemble a socially unmistakable country with aims to develop an up to date version of that social custom. These ambitions are not all around shared, notwithstanding, specifically in Gulf States... where extra well-grounded research on legitimate practices is required. Discussions about the potential outcomes or the skylines of gender equity stay vital to strains across all over the parts of regions and lawful frameworks. What is to note here is a larger number of countries that are Muslim majority nations, lawful practices have been predictable with a comprehensively dynamic plan (John, 2017; Ramos Meza et al., 2021; Said et al., 2021; Malik Shahzad Shabbir \& Wisdom, 2020; Shahzadi, Ayub, Shabbir, \& Yasmin, 2021).

\section{Islamic Law regarding women rights in Qur'an}

Hazrat Adam is the first human being (man) a creation of God came on earth, along with Hazrat Hawa the first women. In this manner, from the earliest starting point of time, men and women were a couple and allies for one another and both are called as father and mother of human race. In Qur'an there is no distinction among men and women as regards the bestowal of bounty for the great attainments practiced by men or women (DW, 2020). Islam treats them in an equal manner, any one who has a devout existence as indicated in Islam is endorsed in equivalent measures for get salvation in Arabic (FALAH) and endless achievement.

Both male and female are equivalent analyzing their diverse nature and specific disposition. Rights of women, her privileges and duties are equivalent to those of men eventually not proportionate. Their jobs are extraordinary and ultimately this does not suggest that one is sub-par compared to the next. In religion Islam, referring to both male and female can ascend in metaphysical greatness. The best respect given to man by God is "Divine Revelation". Women being equivalent to men have besides feast, dress, and shelter are bona fide to be instructed (Mahar, 2010). An extraordinary accentuation is set down in the Holy Quran on incorporeal uniformity of man and woman, as is clear from the accompanying refrain Lord promises. Islam abrogated each sort of sexual discrimination. Both male and female can achieve profound prevalence. Divine disclosure is the best respect offered on man by God. It is not just male who is respected by the Divine disclosure.

Surah__ "Al-Nisa" attend to the problems of women. It manages the privileges of females and families relatinship, the surrah begins with an intrigue to the solidarity concerning humanity. It asks firmly the privileges of women in the issues of property, legacy and marriage. It makes females qualified for the comparative rigthts to life to respect and property (Muslehuddin, 1977).

Male and Females are very equivalent to one another in their own spheres. The Islamic code of life offer respect to a female as mother who give birth to us, as a spouse who is the best buddy. She possess every rights that are provided to men, however she is just needed to watch virtuousness and rules of ethical quality to affix elementry or fundamental standards of the society.

[Just those of his hirelings who are found out really fearful of God] both male and female are equivalent in the pursuit of knowledge and education. Seven hundred and fifty verses in Holy Qur'an orders Muslims to peruse and consider over the indications of Allah, the nature, the phases of moon the spinning of day and night, the formation of human and death and so on. There indeed isn't a single Qur'anic verse that differentiates men and women in getting education (Bralvi, 1982).

\subsection{Choice of Wife}

Holy Qur'an regards about the relationship among a couple (husband and wife) as an affiliation dependent on bilateral and collective understanding, love and friendship among both equivalent individuals. It is anything but a relationship of prevalent and sub-par, or of 
a chief and sub-ordinate, or of people bound together by a few religious or common impulse. The spouse is allocated the job of a family trough. He is monetary, social and good defender of his significant other. He has the authorization in a family framework. Female as a spouse has never been prevented from securing her privileges, such as holding a budget money, property or obtaining cash. She has an equivalent divide in residential issues and other domestic involvement. She is not been given the responsibility of monetary or financial insurance concerning her family. This is not anything but an instance of hardship, however that of a consolation. Male are the helpers of females since Allah has honored one above so as to the other, and on the grounds that they unreservedly spend their riches.

Regardless of whether separation is chosen the prerogative treatment is required in the interest of men. As indicated by Qur'anic verses and the conventions of Prophet Mohammad (PBUH) the situated of female as mother, spouse, sister and daughter turns out to be crystal clear and precise. In Islam for women there is no uncertainty in her status around her very own home. Islam shows obviously that there ought to be a friendly and serene connection among a couple, even among the guardians. A Muslim spouse never again, lives in herself more willingly as her mans' spouse.

\section{Islamic Law Regarding Women Rights in Hadith}

Prophet Mohammad (PBUH) affirmed that it is necessary as a duty or responsibility on each Muslim men and women to seek after knowledge. It remain the quintessential part of social and cultural development of a society, Islam permits no differentiation in its achievement. The two people (male and female) reserve a privilege to acquire from their folks and close to family members: It is a notable tradition of Prophet Mohammad (PBUH) that depicts the importance of learning for the two people: (male and female) "Anas detailed that Allah's Messenger stated:

[From what is left by parents and those nearest related there is a share for men and a share for women, whether the property be small or large, a determinate share] (AlQuran, 4:7)

The right of woman with regard to her inheritance is well protected and secured under Islamic law. On the off chance, and are expired wishes to deny a women heir by bestowing her share to another family member, he is strictly not allowed to do as such according to Islamic law. Her privilege however secured, her ownership/share is half from that associated to a man. This is a direct result of the quantum related to financial obligations that lay on a man for the fact that he is provider by means of livelihood to the family. Aside from a couple of special cases, a man needs to accommodate his family and destitute family members and has additionally to make altruistic commitments as per his riches to support society as a whole. A female is, then again, accommodated and is monetarily secure. As a girl/daughter, it is the responsibility of father to gives her to; as a spouse the husband gives her to; whereas, as a mother her child/son has the responsibility for monetary surety. Because of this safety, and nonappearance of any money related duties, a female's offer in legacy is half as compare to man. A female has each option to enter legally binding understandings, and take part in undertakings of trade. She has the option to acquire and get advantage from her income:

[To men is allotted what they earn, and to women what they earn] (Al-Quran, 4:32)

History uncovers that women have been dynamic members in general life alongside early Muslims. They were particularly dynamic in the midst of crisis and war, nursing the ill and injured, getting ready supplies, and so on. In the life of women, property and respect are sacrosanct in religion Islam.

The punishment forced on her for an offense submitted is equivalent to that of a man. So also, her entitlement to remuneration if there should be an occurrence of enduring mischief is equivalent to that of a man. Lady is held similarly obligated as men with respect to offenses of both common as well as of criminal nature. Opportunity to express opinion is completely permitted to male and female similarly, women contended and took an interest in significant talks amid Prophet Mohammad (PBUH) and communicated their conclusion 
openly. Women counseled Prophet Mohammad (PBUH) in regards to their job in war as well as in their home alongwith other social issues identified with religion, economy and governmental issues. On certain events they had an honest and confident, fearless talk with Prophet Mohammad (PBUH), they acclimated to put their very own perspective frankly infront of different companions. Prophet Mohammad (PBUH) consistently listened persistently and attempted to fulfill them. Prophet Mohammad (PBUH) never debilitated them even at the events when women communicated their perspectives on issues related to public interest, and communicated their resistance to the caliphs, who recognized their perspective for example once a female straightforwardly rubuked Hazrat Omar (Second Caliph), in mosque filled with adorers, over an issue identified/relevant with women. Omar recognized her perspective infront of the considerable number of individuals, and acknowledged that he was not right and the women was correct. Despite the fact that; he was the most influential and powerful ruler he continued his sermon in the wake of submission his recreations to her.

Taking a gander at the women one needs to wed is collectively permitted by the Muslim legal scholars. A portion of the researchers like Ibn-e-Hazm considered that one should take a gander at the lady before offering marriage so as to discover that he is tempt in to her. As indicated by Ibn-e-Rushd greater part of the legal scholars considers it to permit the proposing couple to see one another

There are six kinds of characteristics of parity under Hanafi law are: Religion, Nasab, Profession, Character, method and liberty (Khan, 1998). Prophet Mohammad (PBUH) said: command you good will for your wives for they are your captives, (AbiDawud, Nikkah 41). Consequently; dower sum or whatever other blessing which a spouse may have bestowed to his women other cannot be removed. These were the improvements of Prophet Mohammad (PBUH) which denoted another new set of intended actions throughout the entire history of enactment. Mohammad (PBUH) restricted the intensity of separation controlled by the spouse, he provided for the women the privilege to separate. Separation is used to be the most unlikely and final expedient in Islam. Prophet Mohammad (PBUH) announced 'talaq' as being most vile before God of all allowed things. In the event that the couple reaches to a compromise they may continue their relationship whenever, however inside the waiting period, and the repudiation of separation naturally happens. In the event that the circumstances turns out badly and go wrong by and by and separation is announced for a subsequent second time, a similar methodology is to be pursued. In any case, if the separation is announced for third time talaq gets authoritative or unalterable. After a slip by of three successive months, the spouse is allowed to wed another man, on the off chance that she wants so. The first spouse can't remarry her aside from following the system of "Hallala" (the wife being hitched and separated by another man) (Mahar, 2018).

\section{Discussion and Analysis}

From an Islamic perspective the motivation behind marriage isn't a simple material requirement for the pleasure throughout life, despite what explains in religion Islam clarifies the profound idea of marriage. Marriage is a societal establishment which produces true serenity Since it is God, who creates the spirit accomplices of every single person, so therefore this association gives relief, quit of psyche, mutual comprehension, love kindness and rest of spirit (soul). As per Ibn-e-Maja marriage is a sunna for the individuals who can manage. So, it is additionally a type of love by which one may accomplish closeness to God.

A marriage is null or invalic when it is covenant in the absence of witnesses, or if these witnesses are in inebriated state or with a fifth spouse, four previously being there, With a lady watching iddat. Among grown-ups, and either spouse or wife doesn't express assent. On the off chance that proposition and its acknowledgment are not made or given in a similar gathering. With two sisters simultaneously. A marriage is likewise null on the basis of association/cognation, resonance and fosterage. A void marriage isn't perceived as a marriage by any stretch of the imagination. It doesn't establish any privilege or commitment between the accomplices. As indicated in section 2(ii), Dissolution of Muslim Marriages Act 1939, a spouse has a privilege of dissolving her marriage on the off chance that she demonstrates: If marriage was incurred before she achieved the age of fifteen (15) 
years, and; if women would not recognize her marriage before accomplishing the age of eighteen (18) years.

In the Islamic idea of domestic life a women enjoys a place of respect and genuine worth as a mother, spouse, sister and daughter in her household life, her privileges are legitimately secured. She is an equivalent member in local issues with her male accomplice however a few times it appears that she is a stage forward than man. For instance she appreciates an offer in man's acquiring yet man can't have an offer, in her income. She may guarantee cash for raising his youngsters or for doing household tasks. Doing family unit work isn't her legitimate obligation and she may request its payment. A spouse ought to be appreciative to his better half, in the event that she deals with his home joyfully. It is her support to him in the event that she thinks of it as her to do as such.

It is an enactment gone through the mouth of its author for every one of the devotees of the faith, as people bound in their associations to other people just by equity, which is a definitive profound quality of the world referring all the more obviously how, generally the marriage of Islam is an object of law, an understanding for specific purposes and with specific outcomes between individuals viewed in their ability as operators in an extremely human world obligation. A woman carries out various jobs in her home. She is not deposed of her dynamic status in the issues related with the general public. Her commitment is recognized in every field of life. In the issues of religious reverence and devotion to spiritual things she is viewed as equivalent with man. The equivalent is the situation in scholarly field, where she appreciates total uniformity with man, since knowledge seeking is mandatory for the two people (men and women).

In religion Islam a man and women tie themselves by an agreement which allows a few privileges of support, progression and some different rights, in light of shared love and solace the agreement can be revoked at man's will. The lady who is separated or bereaved can enter upon a new agreement with another spouse and she is empowered and helped.

\section{Conclusion}

This research paper has endeavored to analyze women rights in religion Islam, and their infringement in our civilization. I have endeavored to depict a portion of the laws (Islamic laws) so as to find out the situation of women in the domestic circle of life. It shows up from our research that notwithstanding formal arrangements for complete uniformity among men and women under these regulations; it seems that women are as yet and still dependent upon brutality inside their very own families in our culture.

Holy Quran makes it clear that men and women are associated before God with indistinguishable obligations and duties. We should recollect that no religion has accomplished such a great deal of what the religion Islam has done to protect rights of women flawless and thriving. A spouse is advised to be progressively tolerant. He ought not to be irate with his better half rapidly, in light of the fact that she is increasingly emotional. The spouse is to assert his wife and kids. As per the lessons of Islam women have their autonomous entity. In view of marriage she doesn't turn into a hireling or sub-worker of her husband. The matrimony forces some new obligations to her; however it likewise gives her some novel rights. So the agreement of marriage presents a few rights and obligations. It is matrimony that brings forth family life. It gives men and women a genuine feeling of serenity and quietness. Islam not just grants women the privilege to choose marriage, yet in addition the privilege to separate from specific advances and holding up periods must be watched. Any factual elucidation of Qur'anic verses and Hadiths will discover clear confirmations of women's rights equity with that of man, these incorporate the privilege to education, the privilege to work outside, the privilege to cast a ballot and their entitlement to have and express their very own feelings.

In the paper it has explained, that a women's commitments toward the Islamic standards and practices, affirmed by numerous Qur'anic verses and Hadiths, are equivalent to those of a man. Women cannot be excluded from any of these commitments on account of being women or gender distinctiveness. It is clarified there is nothing inalienable in Islam to avoid the balance of men and women. The degraded status of Muslim women today is an 
aftereffect of the inflexible and sick elucidations of Islam. The status of Muslim women as patriarchal position is because of culture and tradition which in no way equipped in any writings from the Quran as well as the Hadiths. Islam truly required the strengthening of women. Islam's order of fairness among men and women requires that all types of brutality against women be annihilated, for such a long time as women endure mishandles, due to un-Islamic practices women are not been able to accomplish their maximum capacity as free and equivalent individuals from society. It is important that women must be educated to know Islam-given privileges/rights in order to differentiate among what is culture or custom. Moreover, what are the teachings of Islam on the off-chance as they wish to be succeeded and to live an honorable life?

\section{References}

AbiDawud, S. (Nikkah 41).

Ahmed, A. M., S. (2010). The Islamic Tradition and the Human rights Discourse, The Gender and Women's rights in Islam: Atlantic Council.

AL-AHSAN, A. (1999). The origin of human history and the first man. Islamic studies, $38(1), 63-86$.

Al-Hibri, A. (2000). An introduction to Muslim women's rights. Windows of faith: Muslim women scholar-activists in North America, 51-71.

Al-Quran. (4:7).

Al-Quran. (4:32).

Altaf, K., Ayub, H., Shabbir, M. S., \& Usman, M. (2021). Do operational risk and corporate governance affect the banking industry of Pakistan? Review of Economics and Political Science.

Arif, A., \& Shabbir, M. S. (2019). Common currency for Islamic countries: is it viable? Transnational Corporations Review, 11(3), 222-234.

Badawi, J. A. (1995). Gender equity in Islam (Vol. 2): by IDM Publications.

Bralvi, A., R, K (1982). The Holy Quran - Urdu translation by Ahmad Raza Khan Bralvi with interpretation by Maulana Naeem-ud-din Muradabadi (Vol. 11). Lahore: Quran Company Ltd, Urdu Bazar.

DW. (2020, 22-05-2020). Women's rights in Islam: Fighting for equality before the law. Retrieved from https://www.dw.com/en/womens-rights-in-islam-fighting-forequality-before-the-law/a-53539222

Eide, M. (2008). "The Stigma of Nation": Feminist Just War, Privilege, and Responsibility. Hypatia, 23(2), 48-60.

Elius, M. (2010). Islamic view of women leadership as head of the state: A critical analysis. Arts Faculty Journal, 195-205.

FT. (2021, August-2021). Taliban pledges to respect women's rights 'within framework of Islam. Retrieved from https://www.ft.com/content/7f03429a-8d61-43df-9cd8c9d9e9ba18c8

Henning, K. (2016). Gender and women's rights in Islam. KfW Development Research.

Hunter, M. (2008). Integrating the philosophy of Tawhid: an Islamic approach to organizationll. In: Universiti Malaysia Perlis.

John, R. B. (2017). Gender, Islam, and law. In (Vol. 2017). Helsinki, Finland: UNU-WIDER.

Khan, R., S, A. (1998). Muhammadan Law. 2, 328.

$\mathrm{Kia}, \mathrm{A}$. (2019). The concept of responsibility of men and women in Islam. Art Human Open Acc J, 3(5), 247-251. doi:10.15406/ahoaj.2019.03.00137

Mahar. (2010). Status of Women in Islam, FPSC Descriptive Tests' Notes by Amir Mahar. Retrieved from www.CSSExamPoint.com

Mahar. (2018). Status of Women in Islam, FPSC Descriptive Tests' Notes by Amir Mahar. Retrieved from www.CSSExamPoint.com

Matloob, T., Shabbir, M. S., \& Saher, N. (2020). Women's political representation in the local governance of Azad Jammu and Kashmir, Pakistan. Review of Economics and Political Science.

Muslehuddin, M. (1977). Sociology and Islam: A comparative study of Islam and its social system: Islamic Publications.

Offenhauer, P., \& Buchalter, A. R. (2005). Women in Islamic societies: A selected review of social scientific literature.

PBS. (2007). Women in 7th century. Retrieved from

https://www.pbs.org/muhammad/ma women.shtml 
Ramos Meza, C. S., Bashir, S., Jain, V., Aziz, S., Raza Shah, S. A., Shabbir, M. S., \& Agustin, D. (2021). The Economic Consequences of the Loan Guarantees and Firm's Performance: A Moderate Role of Corporate Social Responsibility. Global Business Review, 09721509211039674.

Sadiq, M., Usman, M., Zamir, A., Shabbir, M. S., \& Arif, A. (2021). Nexus between economic growth and foreign private investment: evidence from Pakistan economy. Cogent Economics \& Finance, 9(1), 1956067.

Saher, N., Matloob, T., \& Shabbir, M. S. (2020). Exploring the role of Biradari in career growth: Evidence from public sector organizations of Islamabad. Journal of Research in Emerging Markets, 2(3), 13-24.

Said, L. R., Bilal, K., Aziz, S., Gul, A., Shabbir, M. S., Zamir, A., \& Abro, H. (2021). A comparison of conventional versus Islamic banking customers attitudes and judgment. Journal of Financial Services Marketing, 1-15.

Shabbir, M. S. (2019). Informal shariah pawnshop in the traditional markets of Surakarta. Journal of Islamic Marketing. doi:10.1108/JIMA-09-2017-0097

Shabbir, M. S. (2020). Attributes Ensuring Positive Consumer Evaluation in Brand Extension of Pakistan. International Journal of Asian Business and Information Management (IJABIM), 11(4), 71-84.

Shabbir, M. S., Bashir, M., Abbasi, H. M., Yahya, G., \& Abbasi, B. A. (2020). Effect of domestic and foreign private investment on economic growth of Pakistan. Transnational Corporations Review, 1-13.

Shabbir, M. S., Matloob, T., \& Faiz, M. (2017). The way forward for Islamic banking system. Islamic Banking and Finance Review, 4, 68-78.

Shabbir, M. S., \& Wisdom, O. (2020). The relationship between corporate social responsibility, environmental investments and financial performance: evidence from manufacturing companies. Environmental Science and Pollution Research, 27(32), 39946-39957. doi:10.1007/s11356-020-10217-0

Shabbir, M. S., \& Zeb, A. (2020). Nexus and Perception of Customers Toward Conventional Banking Systems: Does the Islamic Banking System Exist as a Competitor? International Journal of Asian Business and Information Management (IJABIM), 11(4), 54-70.

Shahzadi, K., Ayub, H., Shabbir, M. S., \& Yasmin, A. (2021). Factors Affecting Profit Distribution Management of Islamic Banks: Moderating Role of Corporate Governance. Islamic Banking and Finance Review, 8(1), 78-102. doi:DOI: https://doi. org/10.32350/ibfr 